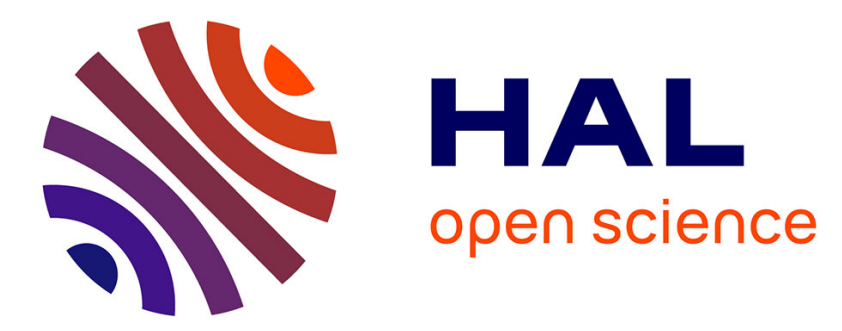

\title{
Potassium Isotope Fractionation During Magmatic Differentiation and the Composition of the Mantle
}

\author{
Yan Hu, Fang-zhen Teng, Rosalind T Helz, Catherine Chauvel
}

\section{To cite this version:}

Yan Hu, Fang-zhen Teng, Rosalind T Helz, Catherine Chauvel. Potassium Isotope Fractionation During Magmatic Differentiation and the Composition of the Mantle. Journal of Geophysical Research:

Solid Earth, 2021, 126 (3), 10.1029/2020JB021543 . hal-03327733

\section{HAL Id: hal-03327733 \\ https://hal.science/hal-03327733}

Submitted on 27 Aug 2021

HAL is a multi-disciplinary open access archive for the deposit and dissemination of scientific research documents, whether they are published or not. The documents may come from teaching and research institutions in France or abroad, or from public or private research centers.
L'archive ouverte pluridisciplinaire HAL, est destinée au dépôt et à la diffusion de documents scientifiques de niveau recherche, publiés ou non, émanant des établissements d'enseignement et de recherche français ou étrangers, des laboratoires publics ou privés. 


\section{Potassium isotope fractionation during magmatic differentiation} and the composition of the mantle

Abstract: 245 words Text: 4892 words Figures: 6 Table: 1

1. Isotope Laboratory, Department of Earth and Space Sciences, University of Washington, Seattle, WA 98195, USA

2. United States Geological Survey, Reston, VA, USA

3. Université de Paris, Institut de Physique du Globe de Paris, CNRS, F-75005 Paris, France

4. Université Grenoble Alpes, ISTerre, CNRS, F-38041 Grenoble, France

\section{2}

(1)

(1)

17

18

20

$25 *$ Corresponding authors:

26 Email: yanhu@uw.edu; fteng@uw.edu 


\section{Abstract}

28 Stable potassium $(\mathrm{K})$ isotopes are emerging as tracers of terrestrial recycling and planetary 29 processes. These applications require well-defined $\mathrm{K}$ isotopic compositions for the mantle and 30 the bulk silicate Earth (BSE). Both values are determined primarily by basalts formed via partial 31 melting of the mantle. Basaltic melts experience igneous differentiation before reaching the 32 surface, which may alter their isotopic compositions compared to their mantle sources. This 33 study investigates $\mathrm{K}$ isotope fractionation during the differentiation and solidification of the 34 Kilauea Iki lava lake, Hawaii, for which crystallization and thermal histories are well 35 documented. High-precision $\mathrm{K}$ isotopic ratios $\left(\delta^{41} \mathrm{~K}\right)$ are measured in thirteen Kilauea Iki 36 samples that cover its complete differentiation history, ranging from olivine-rich, high-MgO 37 cumulates to increasingly differentiated, MgO-depleted samples. The limited $\delta^{41} \mathrm{~K}$ range of $38-0.42$ to $-0.37 \%$ in all but one sample reveals no analytically resolvable fractionation across 39 diverse bulk compositions, even though their bulk $\mathrm{MgO}$ contents varied from 26.87 to 2.37 40 wt.\%. The lack of $\mathrm{K}$ isotopic fractionation is consistent with an absence of K-rich minerals in the 41 crystallizing assemblage, where only plagioclase can accommodate a small amount of K. A 42 highly differentiated vein displays the lowest $\delta^{41} \mathrm{~K}$ of $-0.47 \%$ among the Kilauea Iki suite, 43 which is consistent with our modeling calculations that suggest measurable $\mathrm{K}$ isotope 44 fractionation at more advanced magmatic differentiation stages. Combining our new results with 45 literature data, we propose an average $\delta^{41} \mathrm{~K}$ of $-0.42 \pm 0.08 \%$ (2SD) for the pristine mantle and 46 of $-0.42 \pm 0.07 \%$ (2SD) for the BSE.

48 Keywords: high-precision; potassium isotopes; isotope fractionation; magmatic differentiation; 


\section{Introduction}

Potassium $(\mathrm{K})$ is a primary constituent of planetary crusts and studies of its stable isotope ratio $\left({ }^{41} \mathrm{~K} /{ }^{39} \mathrm{~K}\right)$ have been used recently to provide new insights into planetary accretion and differentiation. Experimental work shows that, as a moderately volatile element, K isotopes fractionate substantially during evaporation-condensation processes (e.g., Yu et al., 2003). Measurements of differentiated lunar and terrestrial lavas indicated that the Moon is enriched in heavy $\mathrm{K}$ isotopes by $\sim 0.4 \%$ o relative to the Earth, which has been interpreted as evaporative loss of light K during the Moon-forming giant impact (Wang and Jacobsen, 2016a). Such interplanetary comparison is based on a key assumption that negligible $\mathrm{K}$ isotope fractionation occurs during igneous differentiation; therefore, crustal rocks are assumed to be representative of their planetary bodies. This assumption is supported by less equilibrium isotope fractionation as temperature increases ( 1/T ${ }^{2}$, Bigeleisen and Mayer, 1947; Urey, 1947). Also, K has a strong tendency to partition into melts during mantle melting and magmatic differentiation. Hence crystal-melt fractionation is not expected to significantly influence the $\mathrm{K}$ budget and isotopic composition of evolving magmas. However, despite these theoretical considerations, there is sparse confirmation in natural samples.

Potassium occurs in several major silicate groups that are commonly involved in magmatic differentiation. Plagioclase crystallization is widely associated with basaltic differentiation while crystallization of K-rich hornblende, biotite, and K-feldspar occurs in more evolved magmas. The sparse $\delta^{41} \mathrm{~K}$ data reported for these minerals span a range of $0.6 \%$, with biotite being isotopically lighter than typical igneous rocks and feldspar being mostly heavier except a few outliers (Chen et al., 2019; Morgan et al., 2018). Their contrasting preferences for K isotopes could reflect differing $\mathrm{K}$ coordination environments between crystallized minerals and melts, or among various K-bearing minerals. Theoretical calculations also suggest that the K-O bond strength of a mineral varies with its chemical composition, for example, feldspar with lower $\mathrm{K} /(\mathrm{K}+\mathrm{Na})$ has stronger $\mathrm{K}-\mathrm{O}$ bond and higher $\delta^{41} \mathrm{~K}$ values (Li et al., 2019; Zeng et al., 2019). Crystallization of these common K-bearing minerals may thus lead to resolvable $\mathrm{K}$ isotope fractionations in differentiated rocks.

The only published study of $\mathrm{K}$ isotope fractionation during magmatic differentiation examined 24 lavas erupted from Iceland's Hekla volcano, and no resolvable variation in $\delta^{41} \mathrm{~K}$ has been observed across basalts to rhyolites ( $-0.46 \pm 0.07 \%$, 2SD; Tuller-Ross et al., 2019a). It 
should be noted that the compositions of Hekla basalts (e.g., $\mathrm{MgO}<5.6 \mathrm{wt} \%$, Savage et al., 2011) are evolved significantly from primitive basaltic magmas (e.g., $\mathrm{MgO}=11-14$ wt\%; Niu, 1997). Therefore, it is uncertain if $\mathrm{K}$ isotope fractionation occurs during early differentiation and if these evolved melts still preserve mantle $\delta^{41} \mathrm{~K}$ signatures. Analyses on a larger set of 51 oceanic basalts from diverse geographic locations and tectonic settings revealed wider K isotopic variability ( -0.66 to $0.03 \%$, 2SD, Tuller-Ross et al., 2019b). The variability could reflect a combination of source heterogeneity, igneous process, and post-eruption alteration, yet it is difficult to isolate and evaluate the contribution from each. Furthermore, these basalts have a limited range of major element composition that is not ideal for evaluating the effect of magmatic differentiation.

This study investigates the extent of $\mathrm{K}$ isotope fractionation within samples from the wellcharacterized Kilauea Iki lava lake, Hawaii. This lava lake is the quintessential example of closed-system differentiation of basaltic magmas. Its accessibility for drilling throughout its cooling and differentiation history has provided a unique opportunity to study partially molten and solidifying lavas that capture crystallization in process and in situ. Recovered drill core and eruption pumice samples have a broad range of chemical composition due to internal differentiation of the lava lake (Helz, 1987a,b; Helz and others, 1994; Murata and Richter, 1966). Notably, this sample suite contains a broad spectrum of rock types and compositions, with bulk $\mathrm{MgO}$ content ranging from 26.9 to $2.37 \mathrm{wt} \%$. Among them, the olivine-rich cumulates are the most magnesian samples analyzed for $\mathrm{K}$ isotopes with high-precision to date, and the olivine basalts are more primitive than the Hekla samples (Fig. 1A and B). These samples decipher whether $\mathrm{K}$ isotopes fractionate during early-stage differentiation of mantle-derived magmas and whether basalts are isotopically representative of their mantle sources. The more $\mathrm{SiO}_{2}-$ and $\mathrm{K}_{2} \mathrm{O}-$ rich differentiated samples offer insights into how $\mathrm{K}$ isotopes fractionate during advanced stage of magmatic evolution. Combining the new Kilauea Iki data presented here with published igneous $\delta^{41} \mathrm{~K}$ values, this study provides the most up-to-date averages for the mantle and bulk silicate Earth (BSE). 


\section{Geological background and samples}

Kilauea is a highly active volcano sitting on the southeastern flank of the massive Mauna Loa shield volcano on the Island of Hawaii. During the 1959 summit eruption, a large volume of magma ponded into a pre-existing 135-meter-deep pit crater east of the main Kilauea caldera, forming the Kilauea Iki lava lake. The upper crust stabilized by December 24, 1959, after which the interior of the lake cooled, crystallized, and differentiated over several decades as a closed system.

Thirteen samples analyzed here are the same as those used in previous studies to constrain the isotope fractionation behaviors of $\mathrm{Li}, \mathrm{Mg}, \mathrm{Ca}, \mathrm{Ti}, \mathrm{Cr}, \mathrm{Fe}, \mathrm{Cu}, \mathrm{Zn}, \mathrm{Ga}, \mathrm{Sr}, \mathrm{Zr}$, and $\mathrm{Sn}$ (Amsellem et al., 2018; Badullovich et al., 2017; Chen et al., 2013; Inglis et al., 2019; Johnson et al., 2019; Kato et al., 2017; Savage et al., 2015; Shen et al., 2020; Teng et al., 2008, 2010; Tomascak et al., 1999; Zhang et al., 2018; Zhao et al., 2020). They include 11 drill core samples from the lava lake and two eruption pumices. Four samples are olivine-rich cumulates, five are olivine tholeiites, and three are differentiated samples, including one ferrodiabase, and two rare, more differentiated veins. This suite of samples encompasses the full range of whole-rock compositions in Kilauea Iki (Table 1; Fig. 1A and B). The substantial variation in MgO content is primarily controlled by accumulation or fractionation of olivine. $\mathrm{K}_{2} \mathrm{O}$ content increases with decreasing $\mathrm{MgO}$, and varies from 0.19 to 1.99 wt.\% (Fig. 1A). For samples with less than 7.5 wt $\% \mathrm{MgO}$, the coinciding decrease in $\mathrm{CaO}$ and $\mathrm{MgO}$ is indicative of crystallization of augite and plagioclase. The complete crystallization sequence is olivine + chromian spinel, augite, plagioclase, ilmenite, pigeonite/orthopyroxene, magnetite, and apatite. This sequence, except for apatite, was determined experimentally and reported in Helz and Thornber (1987).

Four igneous rock standards are measured to assess data quality and to compare with oceanic basalts. These standards are selected to include a wide range of tectonic settings and chemical compositions. The basalt standard BCR-1 is from Columbia River, U.S.A., one of the bestpreserved continental flood provinces (e.g., Carlson et al., 1984). JB-1 is an alkali basalt from Kitamatsuura Peninsula, Japan, mainly composed of olivine, augite, and plagioclase (Terashima et al., 1998). Two more evolved intrusive rock standards are also analyzed, including a diorite (DR-N) from France and a granite (GBW07103) from China. 


\section{Analytical Methods}

Potassium isotopic analyses were carried out in the Isotope Laboratory at the University of Washington, Seattle. Chemical separation of K follows the procedure of Xu et al. (2019). In brief, pulverized samples are dissolved in screw-top Teflon beakers using sequential mixtures of Optima-grade concentrated $\mathrm{HF}-\mathrm{HNO}_{3}, \mathrm{HCl}-\mathrm{HNO}_{3}$, and finally $\mathrm{HNO}_{3}$ on a hotplate. Sample solutions are dried down between each step. Once fully dissolved, sample solutions were evaporated to dryness, redissolved in $0.5 \mathrm{~N} \mathrm{HNO}_{3}$, then passed twice through polyethylene columns (Bio-Rad Poly-Prep) containing 2 mL cation exchange resin (Bio-Rad AG 50W-X8, 200-400 mesh). Matrix elements are eluted with $0.5 \mathrm{~N} \mathrm{HNO}_{3}$ and $\mathrm{K}$ fraction is collected subsequently using the same acid.

Potassium isotopic compositions are measured on a Nu Plasma II multi-collector inductively coupled plasma mass spectrometer (MC-ICPMS) following the protocol described in $\mathrm{Hu}$ et al. (2018). The K standard used in this study is Standard Reference Material (SRM) 3141a from the National Institute of Standards and Technology (NIST). Sample solutions and K standard solutions are diluted to the same $\mathrm{K}$ concentrations using 3\% Optima-grade $\mathrm{HNO}_{3}$, and they are measured alternately to correct for instrumental mass bias. An Aridus II desolvation nebulizer system is fitted to the plasma source, and the plasma is operated at reduced RF power to minimize argon-related interferences. Ions beams of ${ }^{41} \mathrm{~K}^{+}$and ${ }^{39} \mathrm{~K}^{+}$were measured simultaneously on interference-free peak shoulders. A blank was measured at the beginning of each analytical session and was subtracted from the measured ion beams. Potassium isotopic data are reported as the average of $\mathrm{N}$ repeated analyses $(\mathrm{N} \geq 6)$ relative to NIST SRM 3141a in delta notation:

$$
\delta^{41} \mathrm{~K}(\% \mathbf{0})=\left\{\frac{\left({ }^{41} \mathrm{~K} /{ }^{39} \mathrm{~K}\right)_{\text {sample }}}{\left({ }^{41} \mathrm{~K} /{ }^{39} \mathrm{~K}\right)_{\text {NIST SRM 3141a }}}-1\right\} \times 1000
$$

The average of $\mathrm{N}$ repeated analyses is reported for each sample along with uncertainties calculated as both 2SD (standard deviation) and 95\% c.i. (confidence interval) [see $\mathrm{Hu}$ et al. (2018) for details]. It has been demonstrated in detail in a previous study that $\mathrm{K}$ isotopic ratios can be measured accurately and precisely within 0.06\% (Hu et al., 2018; Hille et al., 2019; Xu et al., 2019). The $\delta^{41} \mathrm{~K}$ values of four rock standards analyzed during the course of this study agree well with published results, which provide additional assurance on the accuracy of our analyses 
167 (Table 1). To further reduce analytical uncertainty and better resolve $\delta^{41} \mathrm{~K}$ variation associated with magmatic differentiation, we also processed full replicates, including sample dissolution, column chemistry, and instrumental analysis, for the five more evolved samples within the 13 Kilauea Iki suite. All replicates yield consistent $\delta^{41} \mathrm{~K}$ values.

\section{Results}

Twelve out of the 13 Kilauea Iki samples display a rather limited $\delta^{41} \mathrm{~K}$ range from -0.42 to $-0.37 \%$ regardless of their wide chemical variations (Fig. 1C). The USGS basalt standard BHVO-1 that was derived from the 1919 Kilauea eruption has a $\delta^{41} \mathrm{~K}$ value of $-0.41 \%$ o (Xu et al., 2019), falling within the range reported here. Including the BHVO-1, 12 basaltic samples from Kilauea Iki yield an average $\delta^{41} \mathrm{~K}$ of $-0.40 \pm 0.03 \%$ (2SD) (Fig. 1C). They are isotopically indistinguishable from the two other basalt standards (BCR-1 $=-0.40 \%$ ond JB-1 $=-0.42 \%$ ), as well as the Hekla basalts, although they originated from different tectonic settings (Fig. 1D). These basalts span a considerably narrower range than that was reported previously for midocean ridge basalts (MORBs) and oceanic island basalts (OIBs) (Tuller-Ross et al., 2019b) (Fig. 1D).

The only isotopically distinctive sample is a highly differentiated vein (67-2-85.7), which has the lowest $\delta^{41} \mathrm{~K}$ of $-0.47 \%$ within the suite (Fig. 1C). Its $\mathrm{K}$ isotopic composition falls within the range of Hekla andesites (Fig. 2A), and is similar to the diorite (DR-N, -0.52\%o) and granite (GBW07103, -0.49\%) standards measured in this study. The other highly differentiated vein (81-2-88.6) has a $\delta^{41} \mathrm{~K}$ of $-0.37 \%$, indistinguishable from the more primitive samples. These two vein samples, with the highest $\mathrm{K}_{2} \mathrm{O}$ contents $(\sim 2 \mathrm{wt} \%)$, also bracket the range of $\mathrm{K}$ isotopic composition measured for the Kilauea suite.

\section{Discussion}

The first part of the discussion focuses on negligible $\mathrm{K}$ isotope fractionation observed during basaltic differentiation of the Kilauea Iki lava lake. Furthermore, the deviation of a highly differentiated vein from the rest of the sample suggests larger fractionation occurring during advanced magmatic differentiation stages. To illustrate this contention, we compare our new measurements with literature data of more evolved compositions. Based on the $\mathrm{K}$ isotope 
197 fractionation behavior during magmatic differentiation, we provide the most up-to-date $\delta^{41} \mathrm{~K}$ 198 averages for the mantle and BSE calculated from all the available data. These values are critical 199 for evaluating crust-mantle recycling and for inter-planetary comparative studies.

\subsection{Negligible $K$ isotope fractionation during basaltic differentiation}

The 1959 Kilauea Iki samples formed by crystallization of a magma that began as a mixture of olivine and melt, with an average composition of 15.43 wt.\% MgO (Wright, 1973). Like other picritic eruptions at Kilauea and Mauna Loa, the 1959 magma contained abundant pre-eruptive olivine in a carrier melt of lower $\mathrm{MgO}$ content (Helz et al., 2014). Accumulation of pre-existing olivine has produced four diverse high- $\mathrm{MgO}$ samples, with $\mathrm{MgO}$ ranging from 19.5 to $26.9 \mathrm{wt} \%$ (Fig. 1A and B). These are the most magnesian samples analyzed for $\mathrm{K}$ isotopes with high precision to date. Different from these cumulates, the five olivine basalts $(\mathrm{MgO}=7.7-13.5 \mathrm{wt} \%$, Table 1) contain minimal excess olivine (Helz, 1987a). Nevertheless, these two groups of samples have similar $\mathrm{K}$ isotopic compositions. This homogeneity in $\delta^{41} \mathrm{~K}(-0.42$ to $-0.37 \%$ ) across a wide range of $\mathrm{MgO}$ contents reflects the fact that olivine is too depleted in $\mathrm{K}$ to affect the $\mathrm{K}$ budget and isotopic composition of the evolving magmas.

Samples with $5 \% \mathrm{MgO}$ or less were produced by fractional crystallization and melt segregation within the lava lake. The liquid line of descent can be seen for $\mathrm{K}_{2} \mathrm{O}$ in Fig. 1A, and for $\mathrm{CaO}$ in Fig. 1B. Fe-Ti oxide crystallization began when $\mathrm{MgO}$ dropped to below 5 wt.\% (Helz, 1987b; Helz and others, 1994). Two samples that represent the extreme differentiates within the Kilauea Iki suite display contrasting $\delta^{41} \mathrm{~K}$ values. Sample 81-2-88.6 formed by gradual seepage of melt into an opening shrinkage crack in its host segregation vein. It has a $\delta^{41} \mathrm{~K}$ value of $-0.37 \%$, similar to the moderately differentiated sample $75-1-75.2(-0.40 \%$ o $)$ and the remainder of the sample suite. By contrast, the other extreme differentiate (sample 67-2-85.7) was separated quickly from its matrix, by oozing into an open borehole. This sample displays a distinguishably lower $\delta^{41} \mathrm{~K}$ value of $-0.47 \%$. The limited $\delta^{41} \mathrm{~K}$ variation in all but one of the extreme differentiates indicates that negligible $\mathrm{K}$ isotope fractionation occurs during crystallization of basaltic magma, so long as the main phases crystallizing are olivine and/or pyroxene, down to temperatures of $1055^{\circ} \mathrm{C}$.

The lack of $\mathrm{K}$ isotope fractionation is consistent with the geochemical characteristics of $\mathrm{K}$. Similar to other alkali and alkali earth elements (e.g., $\mathrm{Li}, \mathrm{Mg}, \mathrm{Ca}, \mathrm{Sr}$ ), $\mathrm{K}-\mathrm{O}$ bond is dominantly 
227 ionic due to a large difference in electronegativity between $\mathrm{K}$ and O. Furthermore, $\mathrm{K}$ occurs 228 primarily in silicate minerals with a single valence state as $\mathrm{K}^{+}$. Therefore, changes in redox state 229 or oxide crystallization does not affect the $\mathrm{K}$ isotopic composition of evolving magmas. In 230 addition, the large ionic radius of $\mathrm{K}$ leads to its high incompatibility with the early crystallization 231 phases (dominantly olivine and pyroxene), and thus the majority of $\mathrm{K}$ tends to stay in the 232 magmas.

233

234

235

236

237

238

239

240

241

242

243

244

245

246

247

248

249

250

251

252

253

254

255

\subsection{Potentially resolvable $K$ isotope fractionation at advanced stage of differentiation}

Small K isotopic differences exist between basalts and chemically more evolved rocks (Fig. $2 \mathrm{~A}$ ), including a vein that is one of the most differentiated hand specimens in Kilauea Iki lava lake, and dacites to rhyolites erupted from the Hekla volcano reported in Tuller-Ross et al. (2019a). While K is highly incompatible with olivine, pyroxene, and Fe-Ti oxide, it has a higher partition coefficient for plagioclase, particularly when only a small fraction of melt remains in the system. Therefore, plagioclase crystallization may result in measurable $\mathrm{K}$ isotope fractionation at advanced stages of magmatic differentiation. This contention is supported by a progressive lowering of average $\delta^{41} \mathrm{~K}$ with increasing $\mathrm{Ba} / \mathrm{Sr}$ (Fig. 2B), which indicates crystallization of plagioclase that removes $\mathrm{Sr}$ but not the larger Ba cation.

The $\mathrm{K}$ isotope fractionation factor between mineral and melt $\left(\Delta^{41} \mathrm{~K}_{\text {mineral-melt }}\right)$ can be estimated using a Rayleigh distillation equation described below:

$$
\delta^{41} \mathrm{~K}_{\text {melt }}=\delta^{41} \mathrm{~K}_{\text {initial melt }}+\Delta^{41} \mathrm{~K}_{\text {crystal-melt }} \times \ln (f),
$$

where $\mathrm{f}$ represents the fraction of $\mathrm{K}$ remaining in the melt, and $\mathrm{f}=\mathrm{F} \times \mathrm{C}_{\mathrm{K} 2 \mathrm{O} \text {, melt }} / \mathrm{C}_{\mathrm{K} 2 \mathrm{O} \text {, initial melt }}$. The fraction of melt remaining $(\mathrm{F})$ can be calculated using a highly incompatible element (e.g., Th) that has a bulk distribution coefficient of approximately zero $\left(D_{T h}=0\right)$ between the crystallization assemblage and melts, and thus $\mathrm{F}=\mathrm{C}_{\mathrm{Th}}$, initial melt $/ \mathrm{C}_{\mathrm{Th}}$, melt. Following Teng et al. (2008), sample 67-3-39 that has a MgO content of $10.7 \mathrm{wt} \%$ is taken to represent the initial melt composition because $\mathrm{MgO}<11 \mathrm{wt} \%$ marks the onset of internal crystallization of the Kilauea Iki lava lake (Helz, 1987b). Under these assumptions, $\sim 20 \% \mathrm{~K}$ is removed when $80 \%$ of the melt is crystallized (Fig. 3A). Despite the removal of $\mathrm{K}$, the $\mathrm{K}_{2} \mathrm{O}$ content of the remaining magmas increased from 0.5 to $2 \mathrm{wt} \%$ due to a faster rate of magma solidification than $\mathrm{K}$ removal into crystallized minerals. The $\mathrm{K}$ isotopic compositions of the Kilauea samples can be explained with $\Delta^{41} \mathrm{~K}_{\text {mineral-melt }}$ of $-0.15 \%$ to $0.5 \%$ (Fig. $3 \mathrm{~B}$ ). 
We further test whether the mineral-melt fractionation factors estimated from Kilauea samples can explain the variation of $\delta^{41} \mathrm{~K}$ documented in published igneous rocks. Although the initial melt compositions of these rocks are unknown, the fraction of remaining melt can be estimated from the $\mathrm{K}_{2} \mathrm{O}$ content of the rocks at a given bulk $\mathrm{K}$ distribution coefficient $\left(\mathrm{D}_{\mathrm{K}}\right)$ using the relation of $\mathrm{C}_{\mathrm{K} 2 \mathrm{O} \text { melt }}=\mathrm{C}_{\mathrm{K} 2 \mathrm{O} \text { initial melt }} \times \mathrm{F}^{(\mathrm{D}-1)}$. The $\mathrm{D}_{\mathrm{K}}$ of 0.15 produces the best match of remaining melt fraction $(\mathrm{F})$ to that estimated from Th (Fig. 3C). This value also agrees with $\mathrm{K}$ partition coefficients for plagioclase constrained from experimental studies (e.g., Philpotts and Schnetzler, 1970; Sun et al., 2017). Using this value, the K isotopic composition of melts differentiated via fractional crystallization can be modelled with a Rayleigh distillation equation 265 described below:

$$
\delta^{41} \mathrm{~K}_{\text {melt }}=\left(\delta^{41} \mathrm{~K}_{\text {initial melt }}+1000\right) \times \mathrm{f}^{(\alpha-1)}-1000,
$$
where $\alpha$ is the fractionation factor defined by $\alpha=\left({ }^{41} \mathrm{~K} /{ }^{39} \mathrm{~K}\right)_{\text {crystal }} /\left({ }^{41} \mathrm{~K} /{ }^{39} \mathrm{~K}\right)_{\text {melt }}$. The published igneous data are enveloped by a range of $\alpha$ from 0.99985 to 1.0005 , which corresponds to $\Delta^{41} \mathrm{~K}_{\text {mineral-melt }}$ of $-0.15 \%$ to $0.5 \%$ (Fig. 3D). The modeled results suggest that sizeable $\mathrm{K}$ isotope fractionation may occur at advanced stages of magmatic differentiation, during which the more K-rich biotite and K-feldspar join the crystallization assemblage in addition to K-depleted plagioclase.

272 The estimated range of isotope fractionation factor seem to be reasonable when compared 273 with published mineral data. Eight feldspar data vary from -0.39 to $-0.08 \%$, with an exceptionally light value of $-0.59 \%$ (Morgan et al., 2018; Chen et al., 2019; note that all Morgan et al.'s data are converted from seawater scale to SRM 3141a scale by adding $0.12 \%$, which represents K isotopic composition of seawater relative to SRM 3141a, Hille et al., 2019; Wang et al., 2020). Therefore, feldspar is on average isotopically heavier than mafic magmas as represented by the Kilauea basalts $(-0.40 \pm 0.03 \%$ ), and crystallization of the isotopically heavy feldspar results in variable $\Delta^{41} \mathrm{~K}_{\text {mineral-melt }}$ between 0.01 to $0.32 \%$. In contrast to feldspar, 8 published data on igneous biotite $(-0.65$ to $-0.38 \%$ ) are isotopically light except a heavier value of $-0.06 \%$ (Morgan et al., 2018). Crystallization of the isotopically light biotite leads to a range of $\Delta^{41} \mathrm{~K}_{\text {mineral-melt }}$ between -0.25 and $0.02 \%$. A decreased bulk $\Delta^{41} \mathrm{~K}_{\text {mineral-melt }}$ is expected when 283 feldspar and biotite crystallize together.

284 The inferred direction of mineral-melt fractionation is, to a first approximation, consistent 285 with their K-O bond strength assessed by K coordination numbers. The coordination numbers of 
$\mathrm{K}$ are estimated to vary between 5 to 7 in silicate melts (Greaves, 1985), which are similar to those in alkali feldspar (e.g., Downs et al., 1996). By contrast, K coordination numbers are higher in trioctahedral micas (e.g., 7 to 11, Cibin et al., 2005), and is consistent with their lower $\delta^{41} \mathrm{~K}$ values. The chemical composition of a mineral could also have a sizeable influence on its K-O bond strength. As an example, theoretical calculations using the density functional theory (DFT) suggest that, at a given $\mathrm{K}$ coordination number, the average $\mathrm{K}-\mathrm{O}$ bond lengths in feldspar increases with increasing $\mathrm{K} /\left(\mathrm{K}+\mathrm{Na}\right.$ ), leading to a decrease in $\delta^{41} \mathrm{~K}$ by $\sim 0.2 \%$ at $1000 \mathrm{~K}$ ( $\mathrm{Li}$ et al., 2019; Zeng et al., 2019). This compositional effect likely contributes to the wide range of $\delta^{41} \mathrm{~K}$ values documented in common K-bearing minerals.

The K-O bond strength of magmas also changes with differentiation. As the magmas evolve toward more felsic compositions, $\mathrm{O}^{2-}$ associated with $\mathrm{K}^{+}$becomes increasingly polarized toward $\mathrm{Si}^{4+}$ that has a higher electronegativity, resulting in an increase in $\mathrm{K}-\mathrm{O}$ bond length and a decrease in Si-O bond length (Ryerson and Hess, 1980). An increase in magma $\delta^{30} \mathrm{Si}$ has been documented during the differentiation of Hekla lavas (Savage et al., 2011). A coupled decrease in $\delta^{41} \mathrm{~K}$ is observed for the average of basalt to rhyolite (Fig. 4A). To test whether $\mathrm{K}$ isotopes fractionate with progressive melt polymerization, we compare the $\mathrm{K}$ isotopic compositions of the Kilauea and published igneous rock values with their non-bridging oxygens per tetrahedrallycoordinated cations (NBO/T), following the equation described in Mysen et al. (1982):

$$
\mathrm{NBO} / \mathrm{T}=(4 \times \mathrm{T}-2 \times 0) / \mathrm{T}=\sum_{i=1}^{i} n M_{i}^{n+} / T,
$$

where $\mathrm{M}^{\mathrm{n}+}$ represents network-modifying cations. It is noted that for highly evolved magmas such as granitic melts, their $\mathrm{K}$ isotopic compositions often extend to values lower than basalts (Fig. 4B). This direction of $\mathrm{K}$ isotope fractionation is consistent with the predicted effect from melt polymerization, additional to crystallization of isotopically heavy feldspar.

Magmatic differentiation arguably plays a stronger role in driving $\mathrm{K}$ isotope fractionations in felsic magmas than in basaltic magmas. Nevertheless, granitic rocks reported so far span a total $\delta^{41} \mathrm{~K}$ variation of 0.2\% (Fig. 4B) (Chen et al., 2019; Huang et al., 2020; Li et al., 2020; Teng et al., 2020; Tuller-Ross et al., 2019a; Xu et al., 2019), which is significantly smaller than the variation of $0.6 \%$ documented in K-rich minerals (Chen et al., 2019; Morgan et al., 2018). The reduced variation in granites may reflect modulation of $\mathrm{K}$ isotopic composition of evolved magmas due to removal of minerals with opposite isotopic fractionation factors, such as simultaneous crystallization of isotopically heavy feldspar and isotopically biotite. In addition, 
317 the increased viscosity of silicic magmas also makes separation of crystals from melt difficult, in

318 particular if there is lack of density contrast between crystallized K-rich minerals and residual 319 melts. Therefore, the bulk granitic rocks display less variable $\mathrm{K}$ isotopic compositions than K320 bearing minerals.

\subsection{The average $K$ isotopic composition of the pristine mantle}

The mantle hosts over $75 \%$ of $\mathrm{K}$ inventory, whereas it has an extremely low $\mathrm{K}$ concentration of 0.03 wt.\% (McDonough and Sun, 1995). Although peridotites are direct samples from the mantle, it is difficult to measure their $\mathrm{K}$ isotopes accurately and precisely due to their low $\mathrm{K}$ concentrations. In addition, the original $\delta^{41} \mathrm{~K}$ signatures of peridotites may be overprinted during transport by host magmas that commonly contain one to two orders of magnitude higher $\mathrm{K}$. Furthermore, peridotites brought to surface are susceptible to chemical weathering that may alter their $\delta^{41} \mathrm{~K}$ values. Our analyses of the Kilauea Iki differentiated rocks demonstrate that negligible $\mathrm{K}$ isotope fractionation occurs during basaltic differentiation (Fig. 1C); therefore, basalts are reliable alternative to peridotites for constraining the $\mathrm{K}$ isotopic composition of the mantle. An added advantage of basalts is that they occur widely and sample the mantle to greater depths, as opposed to peridotites that have limited occurrences and sample mostly the lithospheric portion of the mantle.

The basaltic samples measured in this study, including the Kilauea Iki samples from ocean island setting, and two basalt standards (BCR-1 and JB-1) from continental and arc settings, are characterized by indistinguishable $\delta^{41} \mathrm{~K}$ values (Figs. $1 \mathrm{C}$ and D). Similar homogeneity is observed for the Hekla basalts (Tuller-Ross et al., 2019a) while a noticeably larger variability is seen in a global set of back-arc basin basalts (BABBs), MORBs, and OIBs reported by TullerRoss et al. (2019b) (Fig. 1D). Except for those two heaviest OIB samples (-0.01 and 0.03\%o) that are attributed to seawater alteration, Tuller-Ross et al. (2019b) argued that the $\delta^{41} \mathrm{~K}$ values of remaining basalts are homogeneous because no systematic correlation is observed between $\delta^{41} \mathrm{~K}$ and $\mathrm{K}_{2} \mathrm{O}, \mathrm{SiO}_{2}, \mathrm{~K}_{2} \mathrm{O} / \mathrm{TiO}_{2}, \mathrm{MgO}$, and $\mathrm{Na}_{8.0}$. However, the variation in these basalts ( -0.66 to $-0.25 \%$ ) is substantial relative to their long-term reproducibility $(0.11 \%$, Chen et al., 2019$)$ (Fig. 1D). The few scattered values mainly occur in samples from the Society plumes, East Pacific Rise, and Mid-Atlantic Ridge, where influences of recycled crustal materials are often suggested 
(e.g., Chauvel et al., 1992; Eiler et al., 2000). It is thus possible that these scattered values reflect local source contamination and are not representative of the pristine mantle.

To characterize the $\mathrm{K}$ isotopic composition of the pristine mantle and minimize the influence of crustal recycling, we perform a detailed statistical analysis on a compiled dataset including our new data and published oceanic basalt data (Fig. 5A). Our analyses reveal that most samples cluster around similar $\delta^{41} \mathrm{~K}$ values, displaying a prominent $\delta^{41} \mathrm{~K}$ peak between -0.49 to $-0.34 \%$. They form a Gaussian distribution averaging at $-0.42 \pm 0.08 \%$ (2SD), which excludes the few scattered literature values that cannot be demonstrated unambiguously to represent genuine mantle signatures. This average is indistinguishable from the value of $-0.43 \pm 0.17 \%$ (2SD) calculated by Tuller-Ross et al. (2019b) but has a considerably smaller dispersion.

Compared with oceanic basalts (Fig. 5A), continental basalts and arc lavas has a more heterogeneous distribution in $\delta^{41} \mathrm{~K}$ and a higher frequency of data falling on the low- $\delta^{41} \mathrm{~K}$ side (Fig. 5B). This variability likely reflects local inputs from recycled crustal materials. For instance, subducting sediments are enriched in K (18345 ppm, Plank, 2014) and have substantially fractionated $\delta^{41} \mathrm{~K}$ values acquired during low-temperature fluid rock interactions (Hu et al., 2020). The role of sediment recycling has been identified in a suite of Lesser Antilles arc lavas, where $\delta^{41} \mathrm{~K}$ values display systematic decreasing trends with increasingly enriched radiogenic isotopes $(\mathrm{Sr}, \mathrm{Nd}, \mathrm{Pb}$, and $\mathrm{Hf})$, and both are projecting toward the compositions of local subducting sediments (Hu et al., 2021). Recycling of crustal K has also been proposed by Sun et al. (2020) to explain the variation of -0.81 to $-0.15 \%$ measured in a suite of continental alkali basalts from northeastern China (Fig. 5B). Likewise, the variable $\delta^{41} \mathrm{~K}(-0.66$ to $-0.31 \%$ ) reported for nine Columbia River basalts in Chen et al. (2020) might reflect crustal additions, as has been suggested by previous studies of radiogenic isotopes in basalts from this region (Carlson et al., 1983).

\subsection{The average $K$ isotopic composition of the bulk silicate Earth}

The $\mathrm{K}$ isotopic composition of the BSE serves as a baseline with which extra-terrestrial materials can be compared to provide insights into planetary accretion and differentiation processes. The BSE values proposed previously by Wang and Jacobsen (2016) and Morgan et al. (2018) are based on measurements of rather limited numbers of terrestrial igneous rocks (Fig. 6). Furthermore, both values are referenced to in-house standards that have not been well-calibrated 
to the common K standard NIST 3141a. For instance, the Suprapur K standard used by Wang and Jacobsen (2016) is found to be either isotopically equal to NIST 3141a (Chen et al., 2019) or 0.05\% lower (Ku and Jacobsen, 2020). The seawater standard used by Morgan et al. (2018) has a $\delta^{41} \mathrm{~K}$ value of $0.03 \%$ relative to NIST $999 \mathrm{~b}$, yet seawater reported in Hu et al. (2018) has a $\delta^{41} \mathrm{~K}$ value of $0.14 \%$ relative to NIST 999c, a substitute for the no-longer-available NIST 999b. More recently, Tuller-Ross et al. (2019b) analyzed a larger set of 49 oceanic basalts to define the mantle average, which is also considered by the authors to represent the BSE. However, in addition to the mantle, continental crust is the second major terrestrial reservoir for $\mathrm{K}$, containing over $24 \%$ of the total $\mathrm{K}$ budget. Therefore, both the mantle and continental crust should be included in calculating the BSE value.

In this study, we compiled published igneous data to derive more representative average $\delta^{41} \mathrm{~K}$ values for the mantle and continental crust; these averages and their associated 2SD uncertainties are then weighted by their mass to calculate the average $\delta^{41} \mathrm{~K}$ of the BSE. The calculation presented here represents an improvement from previous estimates that simply considered the arithmetic average and the dispersion of $\delta^{41} \mathrm{~K}$ in several random samples. The upper continental crust is assumed to be represented by felsic igneous rocks, and the weathering of these rocks produces sedimentary rocks that is isotopically complementary to the $\mathrm{K}$ released to the hydrosphere. The 56 compiled felsic (mostly granitic) rocks yield an average $\delta^{41} \mathrm{~K}$ of $-0.45 \pm$ 0.11\%o (2SD) (Fig. 6). The K isotopic composition of the mantle and oceanic crust is taken from the average $\delta^{41} \mathrm{~K}$ of oceanic basalts at $-0.42 \pm 0.08 \%$ (Fig. $5 \mathrm{~A}$ ) given that basaltic differentiation does not fractionate $\mathrm{K}$ isotopes. The relative contributions of the upper continental crust, oceanic crust, and the mantle to the bulk silicate Earth is normalized to $100 \%$ based on parameters presented in Table 8 of Huang et al. (2020). Our calculation yields a weighted average of $-0.42 \pm$ $0.07 \%$ (2SD) for the BSE. This value also agrees with the average of $-0.43 \pm 0.10 \%$ (2SD) obtained from the Gaussian distribution of all compiled igneous data (Fig. 6).

\section{Conclusions}

This study investigates the behavior of $\mathrm{K}$ isotope fractionation during magmatic differentiation, by a combination of high-precision measurements on 13 co-magmatic Kilauea Iki samples and a detailed re-analysis of published data. Our study leads to the following conclusions: 
407 (1) Twelve out of the 13 Kilauea Iki samples display limited $\delta^{41} \mathrm{~K}$ variation from -0.42 to $408-0.37 \%$, despite their widely varying bulk chemical compositions. These results provide 409 direct evidence that basaltic differentiation does not fractionate $\mathrm{K}$ isotopes and thus $\delta^{41} \mathrm{~K}$ $410 \quad$ values measured in basalts are representative of their mantle sources.

411 (2) A highly differentiated vein sample from the Kilauea Iki lava lake has a measurably lower $412 \quad \delta^{41} \mathrm{~K}$ value of $-0.47 \%$. This value is compared with literature data of more evolved igneous 413 rocks, and they are fitted to a Rayleigh distillation model that suggests resolvable $\mathrm{K}$ isotope 414 fractionation may occur at more advanced stages of magmatic differentiation.

415 (3) Combining our new measurements with literature data, we calculate an average $\delta^{41} \mathrm{~K}$ of $416-0.42 \pm 0.08 \%$ (2SD) for the pristine mantle and of $-0.42 \pm 0.07 \%$ o (2SD) for the BSE. These 417 refined baseline values facilitate the application of $\mathrm{K}$ isotopes in studies of crust-mantle 418 recycling and planetary accretion-differentiation processes.

420 Acknowledgements

421 We thank Drs. Ronald S. Sletten for editing and Deze Liu for discussion. Constructive comments 422 from two anonymous reviewers, associate editor Dr. Phil Janney, and editor Dr. Stephen Parman 423 are gratefully acknowledged. This study was financially supported by the ERC SHRED (grant $n^{\circ}$ 424 833632). This is IPGP contribution $n^{\circ} 4199$. All data reported in this manuscript are in Table 1. 425 
Tables

427 Table 1. Potassium isotopic composition of rock standards and samples from the Kilauea Iki lava lake, 428 Hawaii

\begin{tabular}{|c|c|c|c|c|c|c|c|c|}
\hline Samples & $\begin{array}{c}\mathrm{SiO}_{2} \\
\text { (wt.\%) }\end{array}$ & $\begin{array}{l}\mathrm{MgO} \\
\text { (wt.\%) }\end{array}$ & $\begin{array}{c}\mathrm{K}_{2} \mathrm{O} \\
\text { (wt.\%) }\end{array}$ & $\begin{array}{l}\delta^{41} \mathrm{~K} \\
(\%)\end{array}$ & $\begin{array}{l}2 \mathrm{SD} \\
(\%)\end{array}$ & $\begin{array}{c}95 \% \text { c.i. } \\
(\%)\end{array}$ & $\mathrm{N}$ & $\begin{array}{c}\mathrm{T} \\
\left({ }^{\circ} \mathrm{C}\right)\end{array}$ \\
\hline \multicolumn{9}{|l|}{ Rock standards } \\
\hline BCR-1 & 54.3 & 3.52 & 1.71 & -0.40 & 0.06 & 0.04 & 7 & \\
\hline JB-1 & 52.4 & 7.71 & 1.43 & -0.42 & 0.04 & 0.03 & 7 & \\
\hline DR-N & 52.9 & 4.40 & 1.70 & -0.52 & 0.09 & 0.05 & 6 & \\
\hline GBW07103 & 72.8 & 0.42 & 5.01 & -0.49 & 0.11 & 0.06 & 6 & \\
\hline \multicolumn{9}{|l|}{ Kilauea Iki suite } \\
\hline KI 81-1-169.9 & 43.7 & 26.9 & 0.25 & -0.41 & 0.06 & 0.04 & 7 & \\
\hline KI 67-3-6.8 & 44.6 & 25.8 & 0.30 & -0.37 & 0.05 & 0.04 & 7 & \\
\hline KI 81-1-210 & 44.9 & 24.5 & 0.21 & -0.41 & 0.08 & 0.04 & 7 & 1135 \\
\hline IKI-22 & 46.7 & 19.5 & 0.35 & -0.40 & 0.07 & 0.05 & 6 & 1216 \\
\hline KI 79-3-150.4 & 48.4 & 13.5 & 0.44 & -0.42 & 0.06 & 0.04 & 6 & \\
\hline KI 75-1-38.9 & 48.4 & 12.5 & 0.48 & -0.39 & 0.06 & 0.04 & 6 & \\
\hline KI 67-3-39 & 48.9 & 10.7 & 0.54 & -0.40 & 0.07 & 0.04 & 6 & \\
\hline IKI-58 & 49.9 & 8.08 & 0.55 & -0.38 & 0.05 & 0.04 & 6 & 1144 \\
\hline \multirow{2}{*}{$\begin{array}{l}\text { KI 67-3-81 } \\
\text { re-dissolution }\end{array}$} & 49.8 & 7.73 & 0.63 & -0.38 & 0.07 & 0.04 & 7 & 1055 \\
\hline & & & & -0.38 & 0.09 & 0.04 & 8 & \\
\hline \multirow{2}{*}{$\begin{array}{l}\text { KI 75-1-121.5 } \\
\text { re-dissolution }\end{array}$} & 50.0 & 7.77 & 0.64 & -0.41 & 0.10 & 0.04 & 7 & \\
\hline & & & & -0.42 & 0.11 & 0.04 & 8 & \\
\hline \multirow{2}{*}{$\begin{array}{l}\text { KI } 75-1-75.2 \\
\text { re-dissolution }\end{array}$} & 50.1 & 5.77 & 0.79 & -0.40 & 0.06 & 0.04 & 7 & \\
\hline & & & & -0.40 & 0.09 & 0.05 & 7 & \\
\hline \multirow{2}{*}{$\begin{array}{l}\text { KI } 67-2-85.7 \\
\text { re-dissolution }\end{array}$} & 56.2 & 2.60 & 1.99 & -0.48 & 0.04 & 0.04 & 7 & 1060 \\
\hline & & & & -0.47 & 0.05 & 0.04 & 9 & \\
\hline \multirow{2}{*}{$\begin{array}{l}\text { KI } 81-2-88.6 \\
\text { re-dissolution }\end{array}$} & 57.1 & 2.37 & 1.90 & -0.37 & 0.04 & 0.04 & 7 & \\
\hline & & & & -0.38 & 0.09 & 0.05 & 7 & \\
\hline
\end{tabular}

429 Major element data for rock standards are from http://georem.mpch-mainz.gwdg.de, for Kilauea Iki 430 samples are from Helz et al. (1994) and for Iki-58 and Iki-22 are from Murata and Richter (1966).

431 Quench temperatures for samples containing glass are estimated using $\mathrm{MgO}$ geothermometry of Helz and 432 Thornber

(1987). 


\section{$433 \quad$ Figure captions}

434 Figure 1. Magmatic differentiation in the Kilauea Iki lava lake illustrated by the variations in (A) $435 \mathrm{~K}_{2} \mathrm{O}$ and (B) $\mathrm{CaO}$ contents as a function of $\mathrm{MgO}$ contents. (C) The differentiation led to no 436 resolvable $\mathrm{K}$ isotope fractionation except for a highly differentiated andesite-like vein. Error bars 437 for $\delta^{41} \mathrm{~K}$ in this and following figures indicate $95 \%$ c.i. of the mean. The basalt standard BHVO- 1 438 derived from the 1919 Kilauea eruption is also plotted. The selected samples cover the full ranges of chemical compositions of the lava lake that are indicated by the gray circles and reported in Helz et al. (1994). The Kilauea cumulates and basalts are more primitive than the Hekla volcanic rocks studied by Tuller-Ross et al. (2019a) and are shown by blue diamond symbols. The green horizontal bar represents average $\delta^{41} \mathrm{~K}$ calculated from the basaltic samples. (D) Limited range of $\delta^{41} \mathrm{~K}$ in basalts measured in this study and Hekla basalts as opposed to 444 substantial varability among global oceanic basalts reported in Tuller-Ross et al. (2019b).

445 Figure 2. $\delta^{41} \mathrm{~K}$ in Kilauea Iki and Hekla lavas plotted with indices of magma differentiation. The comparison between the two lava suites suggests a larger $\mathrm{K}$ isotope fractionation in more evolved felsic samples. The horizontal black bars represent the average $\delta^{41} \mathrm{~K}$ for each bulk compositional range and the vertical gray bars represent the $2 \mathrm{SD} . \delta^{41} \mathrm{~K}$ data of the Hekla lavas are from Tuller-Ross et al. (2019a) and their chemical compositions are from Savage et al. (2011). Trace element data for Kilauea Iki samples are from Helz (2012).

Figure 3. Modeled variations in $\mathrm{K}_{2} \mathrm{O}$ and $\delta^{41} \mathrm{~K}$ of the Kilauea Iki samples that underwent crystal fractionation (starting at $\mathrm{MgO}<11 \mathrm{wt} . \%$ ). (A) The fraction of $\mathrm{K}$ retained in melts versus the fraction of melt remaining estimated from Th assuming its bulk distribution coefficient $\left(\mathrm{D}_{\mathrm{Th}}\right)$ equals to zero. The positive correlation suggests that a faster rate of melt solidification than $\mathrm{K}$ removal, consistent with the incompatible behavior during magmatic differentiation (B) $\mathrm{K}_{2} \mathrm{O}$ content in remaining melts versus their $\mathrm{K}$ isotopic compositions. (C) a comparison of estimated remaining melt fraction based on Th concentration and $\mathrm{K}$ concentration at a range of bulk distribution coefficient of $\mathrm{K}\left(\mathrm{D}_{\mathrm{K}}\right)$ between crystallized assemblage and melts. and (D) are 
granitoids (mostly granites) (Chen et al., 2019; Huang et al., 2020; Li et al., 2020; Teng et al., 2020; Tuller-Ross et al., 2019a; Xu et al., 2019) are plotted for comparison.

Figure 4. Potassium isotopic compositions with increasing polymerization. (A) a negative correlation between $\delta^{41} \mathrm{~K}$ and $\delta^{30} \mathrm{Si}$ averaged for each rock type. $\delta^{41} \mathrm{~K}$ data are from Tuller-Ross et al. (2019a) and $\delta^{30} \mathrm{Si}$ data are from Savage et al. (2011). (B) $\delta^{41} \mathrm{~K}$ data plotted as a function of non-bridging oxygens per tetrahedrally-coordinated cations $(\mathrm{NBO} / \mathrm{T})$, which is calculated from the major element composition of each sample assuming total $\mathrm{Fe}$ is $\mathrm{Fe}^{2+}$.

Figure 5. Histograms of compiled $\delta^{41} \mathrm{~K}$ data for (A) oceanic basalts (with $\mathrm{SiO}_{2}<55$ wt.\%) and (B) continental basalts and arc lavas. The blue curve represents Gaussian distribution, and the red curves represent the Kernel Density Estimation (KDE) curves using an online program provided by Vermeesch (2012). Data sources: this study and Chen et al. (2019; 2020), Huang et al. (2020), Li et al. (2020), Sun et al. (2020), Teng et al. (2020), Tuller-Ross et al. (2019a; b), Xu et al. (2019), and Hu et al. (2020b).

Figure 6 Histograms of compiled $\delta^{41} \mathrm{~K}$ data for all igneous rocks. The orange and blue curves represent Gaussian distribution of felsic igneous data and all igneous data, respectively. Data sources: this study and Chen et al. (2019; 2020), Huang et al. (2020), Li et al. (2020), Sun et al. (2020), Teng et al. (2020), Tuller-Ross et al. (2019a; b), Xu et al. (2019), and Hu et al. (2020b). The BSE values calcuated from this study is compared with those proposed in literature by Wang and Jacobsen (2016), Morgan et al. (2018), and Tuller-Ross et al. (2019b). The $\delta^{41} \mathrm{~K}$ value of Wang and Jacobsen (2016) is either $-0.48 \%$ if there is no isotopic difference between NIST 3141a and Suprapur K, as reported in Chen et al. (2019), or $-0.53 \%$ if NIST 3141a is heavier than Suprapur K by $0.047 \%$, as measured by $\mathrm{Ku}$ and Jacobsen (2020). Using a seawater value of 0.03\%o relative to NIST 999b (Morgan et al., 2018), their BSE value of $-0.54 \%$ on seawater scale can be converted to NIST 3141a scale assuming that NIST $999 \mathrm{~b}$ is isotpoically identical to NIST 999c and NIST 3141a (Hu et al., 2018). Alternatively, if using a seawater value of 0.14\%o relative to NIST 999c (Hu et al., 2018), which is consistent with seawater values obtained by Hille et al., (2019) and Wang et al., (2020), the BSE value of Morgan et al. (2018) is converted to $-0.40 \%$. 


\section{References}

492

493

494

495

496

497

498

499

500

501

502

503

504

505

506

507

508

509

510

511

512

513

514

515

516

517

518

519

520

521

522

523

524

525

526

527

528

529

530

531

532

533

534

535

536

537

Amsellem, E., Moynier, F., Day, J.M.D., Moreira, M., Puchtel, I.S., \& Teng, F.-Z. (2018) The stable strontium isotopic composition of ocean island basalts, mid-ocean ridge basalts, and komatiites. Chemical Geology, 483, 595-602. https://doi.org/10.1016/j.chemgeo.2018.03.030

Badullovich, N., Moynier, F., Creech, J., Teng, F.Z., \& Sossi, P.A. (2017) Tin isotopic fractionation during igneous differentiation and Earth's mantle composition. Geochemical Perspectives Letters, 5, 24-28. https://doi.org/10.7185/geochemlet.1741

Bigeleisen, J., \& Mayer, M.G. (1947) Calculation of Equilibrium Constants for Isotopic Exchange Reactions. The Journal of Chemical Physics, 15, 261-267. https://doi.org/10.1063/1.1746492

Carlson, R.W., Lugmair, G.W., \& Macdougall, J.D. (1983) "Columbia River volcanism: the question of mantle heterogeneity or crustal contamination" (reply to a comment by D. J. DePaolo). Geochimica et Cosmochimica Acta, 47, 845-846. https://doi.org/10.1016/0016-7037(83)90118-7

Carlson, R.W. (1984) Isotopic constraints on Columbia River flood basalt genesis and the nature of the subcontinental mantle. Geochimica et Cosmochimica Acta, 48, 2357-2372. https://doi.org/10.1016/0016-7037(84)90231-X

Chauvel, C., Hofmann, A.W., \& Vidal, P. (1992) HIMU-EM: The French Polynesian connection. Earth and Planetary Science Letters, 110, 99-119. https://doi.org/10.1016/0012-821X(92)90042-T

Chen, H., Savage, P.S., Teng, F.-Z., Helz, R.T., \& Moynier, F. (2013) Zinc isotope fractionation during magmatic differentiation and the isotopic composition of the bulk Earth. Earth and Planetary Science Letters, 369-370, 34-42. https://doi.org/10.1016/j.eps1.2013.02.037

Chen, H., Liu, X.-M., \& Wang, K. (2020) Potassium isotope fractionation during chemical weathering of basalts. Earth and Planetary Science Letters, 539, 116192. https://doi.org/10.1016/j.epsl.2020.116192

Chen, H., Tian, Z., Tuller-Ross, B., Korotev, Randy L., \& Wang, K. (2019) High-precision potassium isotopic analysis by MC-ICP-MS: an inter-laboratory comparison and refined $\mathrm{K}$ atomic weight. Journal of Analytical Atomic Spectrometry, 34, 160-171. https://doi.org/10.1039/C8JA00303C

Cibin, G., Mottana, A., Marcelli, A. \& Brigatti, M.F. (2005) Potassium coordination in trioctahedral micas investigated by K-edge XANES spectroscopy. Mineralogy and Petrology, 85, 67-87

Downs, R.T., Andalman, A., \& Hudacsko, M. (1996) The coordination numbers of Na and K atoms in low albite and microcline as determined from a procrystal electron-density distribution. American Mineralogist, 81, 1344-1349. https://doi.org/10.2138/am-1996-11-1206

Eiler, J.M., Schiano, P., Kitchen, N., \& Stolper, E.M. (2000) Oxygen-isotope evidence for recycled crust in the sources of mid-ocean-ridge basalts. Nature, 403, 530-534. https://www.nature.com/articles/35000553

Greaves, G.N. (1985) EXAFS and the structure of glass. Journal of non-crystalline solids, 71, 203-5217. https://doi.org/10.1016/0022-3093(85)90289-3

Helz, R.T. (1987a) Diverse olivine types in lavas of the 1959 eruption of Kilauea Volcano, and their bearing on eruption dynamics: in Decker, R.W., Wright, T.L. and Stauffer, P.H., eds., Volcanism in Hawaii: U.S. Geological Survey Professional Paper 1350, pp. 691-722.

Helz, R.T. (1987b) Differentiation behavior of Kilauea Iki lava lake, Kilauea Volcano, Hawaii: an overview of past and current work. Magmatic processes: Physicochemical principles, 1 , 241-258.

Helz, R.T., \& Thornber, C.R. (1987) Geothermometry of Kilauea Iki lava lake, Hawaii. Bulletin of Volcanology, 49, 651-668.

Helz, R.T., Kirschenbaum, H., Marinenko, J., \& Qian, R. (1994) Whole-rock analyses of core samples from the 1967, 1975, 1979 and 1981 drillings of Kilauea Iki lava lake, Hawaii. US Geological Survey Open File Report 94-684, 65 pp. 
Helz, R.T. (2012) Trace-element analyses of core samples from the 1967-1988 drillings of Kilauea Iki lava lake, Hawaii. US Geological Survey Open File Report 2012-1050, 46 pp.

Helz, R. T., Clague, D.A., Sisson, T. W., \& Thornber, C. R. (2014) Petrologic Insights into Basaltic Volcanism at Historically Active Hawaiian Volcanoes: in eds. Poland and Kauahikaua, Characteristics of Hawaiian Volcanoes, USGS Professional Paper 1801, Chapter 6, pp. 237-294, http://dx.doi.org/10.3133/pp1801.

Hille, M., Hu, Y., Huang, T.-Y., and Teng, F.-Z. (2019) Homogeneous and heavy potassium isotopic composition of global oceans. Science Bulletin, 64, 1740-1742, https://doi.org/10.1016/j.scib.2019.09.024.

Hu, Y., Chen, X.-Y., Xu, Y.-K., \& Teng, F.-Z. (2018) High-precision analysis of potassium isotopes by HR-MC-ICPMS. Chemical Geology, 493, 100-108. https://doi.org/10.1016/j.chemgeo.2018.05.033

Hu, Y., Teng, F.-Z., Plank, T., \& Chauvel, C. (2020) Potassium isotopic heterogeneity in subducting oceanic plates. Science Advances, 6, eabb2472. https://doi.org/10.1126/sciadv.abb2472

Hu, Y., Teng, F.-Z., \& Chauvel, C. (2021) Potassium isotopic evidence for sedimentary input to the mantle source of Lesser Antilles lavas. Geochimica et Cosmochimica Acta, 295, 98-111. https://doi.org/10.1016/j.gca.2020.12.013.

Huang, T.-Y., Teng, F.-Z., Rudnick, R.L., Chen, X.-Y., Hu, Y., Liu, Y.-S., \& Wu, F.-Y. (2020) Heterogeneous potassium isotopic composition of the upper continental crust. Geochimica et Cosmochimica Acta, 278, 122-136. https://doi.org/10.1016/j.gca.2019.05.022

Inglis, E.C., Moynier, F., Creech, J., Deng, Z., Day, J.M.D., Teng, F.-Z., Bizzarro, M., Jackson, M., \& Savage, P. (2019) Isotopic fractionation of zirconium during magmatic differentiation and the stable isotope composition of the silicate Earth. Geochimica et Cosmochimica Acta, 250, 311-323. https://doi.org/10.1016/j.gca.2019.02.010

Johnson, A.C., Aarons, S.M., Dauphas, N., Nie, N.X., Zeng, H., Helz, R.T., Romaniello, S.J., \& Anbar, A.D. (2019) Titanium isotopic fractionation in Kilauea Iki lava lake driven by oxide crystallization. Geochimica et Cosmochimica Acta, 264, 180-190. https://doi.org/10.1016/j.gca.2019.08.022

Kato, C., Moynier, F., Foriel, J., Teng, F.-Z., \& Puchtel, I.S. (2017) The gallium isotopic composition of the bulk silicate Earth. Chemical Geology, 448, 164-172. https://doi.org/10.1016/j.chemgeo.2016.11.020

$\mathrm{Ku}$, Y., \& Jacobsen, S.B. (2020) Potassium isotope anomalies in meteorites inherited from the protosolar molecular cloud. Science Advances, 6, eabd0511. https://doi.org/10.1126/sciadv.abd0511

Li, S., Li, W., Beard, B.L., Raymo, M.E., Wang, X., Chen, Y., \& Chen, J. (2019a) K isotopes as a tracer for continental weathering and geological K cycling. Proceedings of the National Academy of Sciences of the United States of America, 116, 8740-8745. https://doi.org/10.1073/pnas.1811282116

Li, X., Han, G., Zhang, Q., \& Miao, Z. (2020) An optimal separation method for high-precision K isotope analysis by using MC-ICP-MS with a dummy bucket. Journal of Analytical Atomic Spectrometry, 35, 1330-1339. https://doi.org/10.1039/D0JA00127A

Li, Y., Wang, W., Huang, S., Wang, K., \& Wu, Z. (2019b) First-principles investigation of the concentration effect on equilibrium fractionation of $\mathrm{K}$ isotopes in feldspars. Geochimica et Cosmochimica Acta, 245, 374-384. https://doi.org/10.1016/j.gca.2018.11.006

McDonough, W.F., \& Sun, S.s. (1995) The composition of the Earth. Chemical Geology, 120, 223-253. https://doi.org/10.1016/0009-2541(94)00140-4

Morgan, L.E., Santiago Ramos, D.P., Davidheiser-Kroll, B., Faithfull, J., Lloyd, N.S., Ellam, R.M., \& Higgins, J.A. (2018) High-precision ${ }^{41} \mathrm{~K} /{ }^{39} \mathrm{~K}$ measurements by MC-ICP-MS indicate terrestrial variability of $\delta^{41} \mathrm{~K}$. Journal of Analytical Atomic Spectrometry, 33, 175-186. https://doi.org/10.1039/C7JA00257B 
Murata, K.J., \& Richter, D. H. (1966) Chemistry of the lavas of the 1959-60 eruption of Kilauea Volcano, Hawaii. U.S. Geological Survey Professional Paper 537-A. 26 pp.

Mysen, B.O., Virgo, D. \& Seifert, F.A. (1982) The structure of silicate melts: Implications for chemical and physical properties of natural magma. Reviews of Geophysics and Space Physics, 20, 353-383. https://doi.org/10.1029/RG020i003p00353

Niu, Y. (1997) Mantle Melting and Melt Extraction Processes beneath Ocean Ridges: Evidence from Abyssal Peridotites. Journal of Petrology, 38, 1047-1074. https://doi.org/10.1093/petroj/38.8.1047

Philpotts, J.A., \& Schnetzler, C.C. (1970) Phenocryst-matrix partition coefficients for K, Rb, Sr and Ba, with applications to anorthosite and basalt genesis. Geochimica et Cosmochimica Acta, 34, 307-322. https://doi.org/10.1016/0016-7037(70)90108-0

Plank, T. (2014) The Chemical Composition of Subducting Sediments, in: Holland, H.D., Turekian, K.K. (Eds.), Treatise on Geochemistry, Second ed. Elsevier, pp. 607-629.

Rudnick, R.L., \& Gao, S. (2014) Composition of the continental crust, in: Holland, H., Turekian, K. (Eds.), Treatise on Geochemistry Elsevier, pp. 1-51.

Ryerson, F.J., \& Hess, P.C. (1980) The role of $\mathrm{P}_{2} \mathrm{O}_{5}$ in silicate melts. Geochimica et Cosmochimica Acta, 44, 611-624. https://doi.org/10.1016/0016-7037(80)90253-7

Savage, P.S., Georg, R.B., Williams, H.M., Burton, K.W., \& Halliday, A.N. (2011) Silicon isotope fractionation during magmatic differentiation. Geochimica et Cosmochimica Acta, 75, 6124-6139. https://doi.org/10.1016/j.gca.2011.07.043

Savage, P.S., Moynier, F., Chen, H., Siebert, J., Badro, J., Puchtel, I.S., \& Shofner, G. (2015) Copper isotope evidence for large-scale sulphide fractionation during Earth's differentiation. Geochemical Perspectives Letters, 1, 53-64. https://doi.org/10.7185/geochemlet.1506

Shen, J., Xia, J., Qin, L., Carlson, R.W., Huang, S., Helz, R.T., \& Mock, T.D. (2020) Stable chromium isotope fractionation during magmatic differentiation: Insights from Hawaiian basalts and implications for planetary redox conditions. Geochimica et Cosmochimica Acta, 278, 289-304. https://doi.org/10.1016/j.gca.2019.10.003

Sun, C., Graff, M., \& Liang, Y. (2017) Trace element partitioning between plagioclase and silicate melt: The importance of temperature and plagioclase composition, with implications for terrestrial and lunar magmatism. Geochimica et Cosmochimica Acta, 206, 273-295. https://doi.org/10.1016/j.gca.2017.03.003

Sun, Y., Teng, F.-Z., Hu, Y., Chen, X.-Y., \& Pang, K.-N. (2020) Tracing subducted oceanic slabs in the mantle by using potassium isotopes. Geochimica et Cosmochimica Acta, 278, 353-360. https://doi.org/10.1016/j.gca.2019.05.013

Teng, F.-Z., Dauphas, N., \& Helz, R.T. (2008) Iron Isotope Fractionation During Magmatic Differentiation in Kilauea Iki Lava Lake. Science, 320, 1620-1622. https://doi.org/10.1126/science.1157166

Teng, F.-Z., Li, W.-Y., Ke, S., Marty, B., Dauphas, N., Huang, S., Wu, F.-Y., \& Pourmand, A. (2010) Magnesium isotopic composition of the Earth and chondrites. Geochimica et Cosmochimica Acta, 74, 4150-4166. https://doi.org/10.1016/j.gca.2010.04.019

Teng, F.-Z., Hu, Y., Ma, J.-L., Wei, G.-J., \& Rudnick, R.L. (2020) Potassium isotope fractionation during continental weathering and implications for global $\mathrm{K}$ isotopic balance. Geochimica et Cosmochimica Acta, 278, 261-271. https://doi.org/10.1016/j.gca.2020.02.029

Tomascak, P.B., Tera, F., Helz, R.T., \& Walker, R.J. (1999) The absence of lithium isotope fractionation during basalt differentiation: new measurements by multicollector sector ICP-MS. Geochimica et Cosmochimica Acta, 63, 907-910. https://doi.org/10.1016/S0016-7037(98)00318-4

Tuller-Ross, B., Savage, P.S., Chen, H., \& Wang, K. (2019a) Potassium isotope fractionation during magmatic differentiation of basalt to rhyolite. Chemical Geology, 525, 37-45. https://doi.org/10.1016/j.chemgeo.2019.07.017 
Tuller-Ross, B., Marty, B., Chen, H., Kelley, K.A., Lee, H., \& Wang, K. (2019b) Potassium isotope systematics of oceanic basalts. Geochimica et Cosmochimica Acta, 259, 144-154. https://doi.org/10.1016/j.gca.2019.06.001

Urey, H.C. (1947) The thermodynamic properties of isotopic substances. Journal of the Chemical Society, 562-581.

Vermeesch, P. (2012) On the visualisation of detrital age distributions. Chemical Geology, 312-313, 190-194. https://doi.org/10.1016/j.chemgeo.2012.04.021

Wang, K., \& Jacobsen, S.B. (2016a) Potassium isotopic evidence for a high-energy giant impact origin of the Moon. Nature, 538, 487-490. https://www.nature.com/articles/nature19341

Wang, K., \& Jacobsen, S.B. (2016b) An estimate of the Bulk Silicate Earth potassium isotopic composition based on MC-ICPMS measurements of basalts. Geochimica et Cosmochimica Acta, 178, 223-232. https://doi.org/10.1016/j.gca.2015.12.039

White, W., Klein, E., Holland, H., \& Turekian, K. (2014) Composition of the oceanic crust. in: Holland, H.D., Turekian, K.K. (Eds.), Treatise on Geochemistry, Second ed. Elsevier, pp. 457-496.

Wright, T.L. (1973) Magma Mixing as Illustrated by the 1959 Eruption, Kilauea Volcano, Hawaii. GSA Bulletin, 84, 849-858. https://doi.org/10.1130/0016-7606(1973)84<849:MMAIBT>2.0.CO;2

Xu, Y.-K., Hu, Y., Chen, X.-Y., Huang, T.-Y., Sletten, R.S., Zhu, D., \& Teng, F.-Z. (2019) Potassium isotopic compositions of international geological reference materials. Chemical Geology, 513, 101-107. https://doi.org/10.1016/j.chemgeo.2019.03.010

Yu, Y., Hewins, R.H., Alexander, C.M.O.D., \& Wang, J. (2003) Experimental study of evaporation and isotopic mass fractionation of potassium in silicate melts. Geochimica et Cosmochimica Acta, 67, 773-786. https://doi.org/10.1016/S0016-7037(02)01176-6

Zeng, H., Rozsa, V.F., Nie, N.X., Zhang, Z., Pham, T.A., Galli, G., \& Dauphas, N. (2019) Ab Initio Calculation of Equilibrium Isotopic Fractionations of Potassium and Rubidium in Minerals and Water. ACS Earth and Space Chemistry, 3, 2601-2612. https://doi.org/10.1021/acsearthspacechem.9b00180

Zhang, H., Wang, Y., He, Y., Teng, F.-Z., Jacobsen, S.B., Helz, R.T., Marsh, B.D., \& Huang, S. (2018) No Measurable Calcium Isotopic Fractionation During Crystallization of Kilauea Iki Lava Lake. Geochemistry, Geophysics, Geosystems, 19, 3128-3139. https://doi.org/10.1029/2018GC007506

Zhao, X., Tang, S., Li, J., Wang, H., Helz, R., Marsh, B., Zhu, X., \& Zhang, H. (2020) Titanium isotopic fractionation during magmatic differentiation. Contributions to Mineralogy and Petrology, 175, 67. 
Figures. 

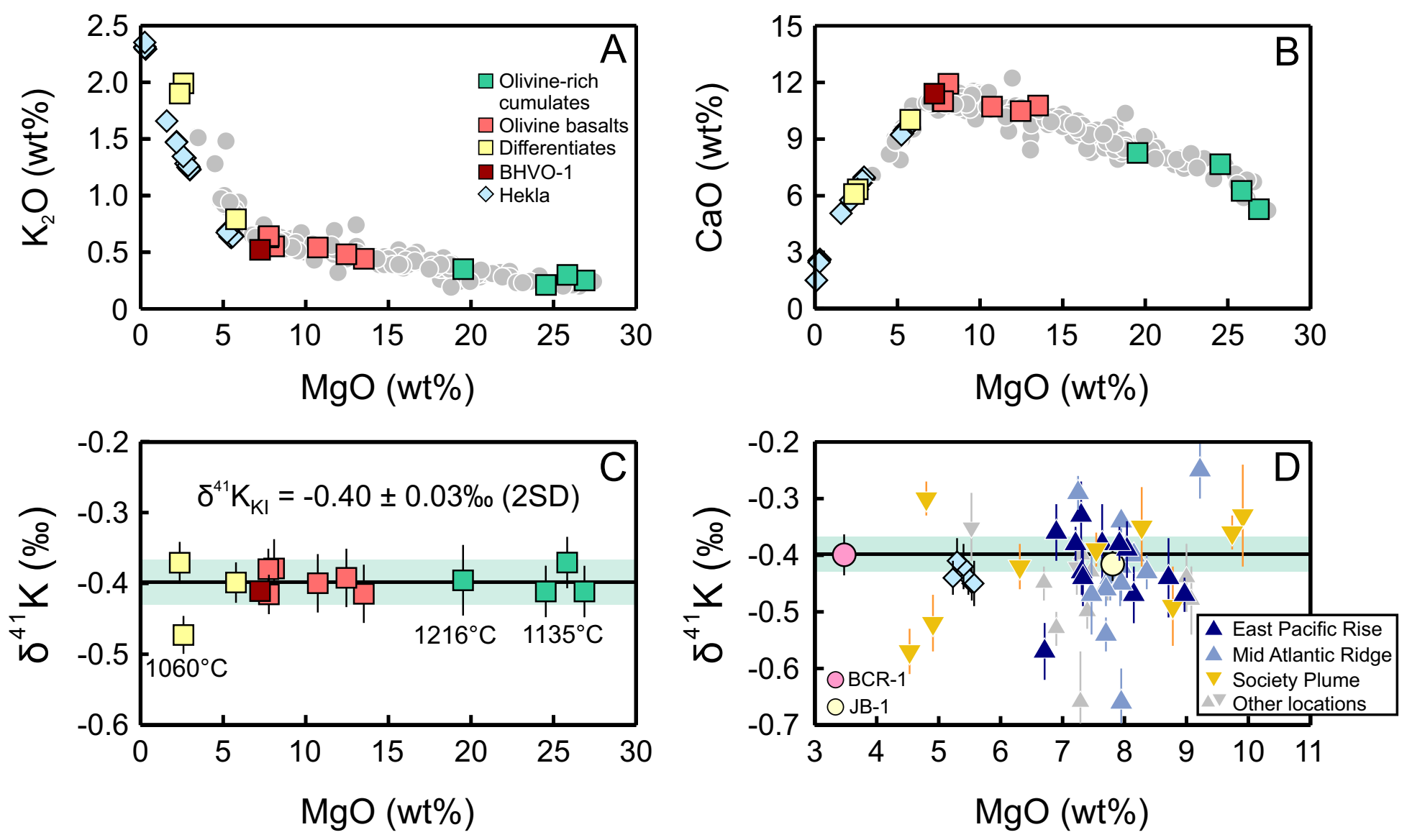

Figure 1 

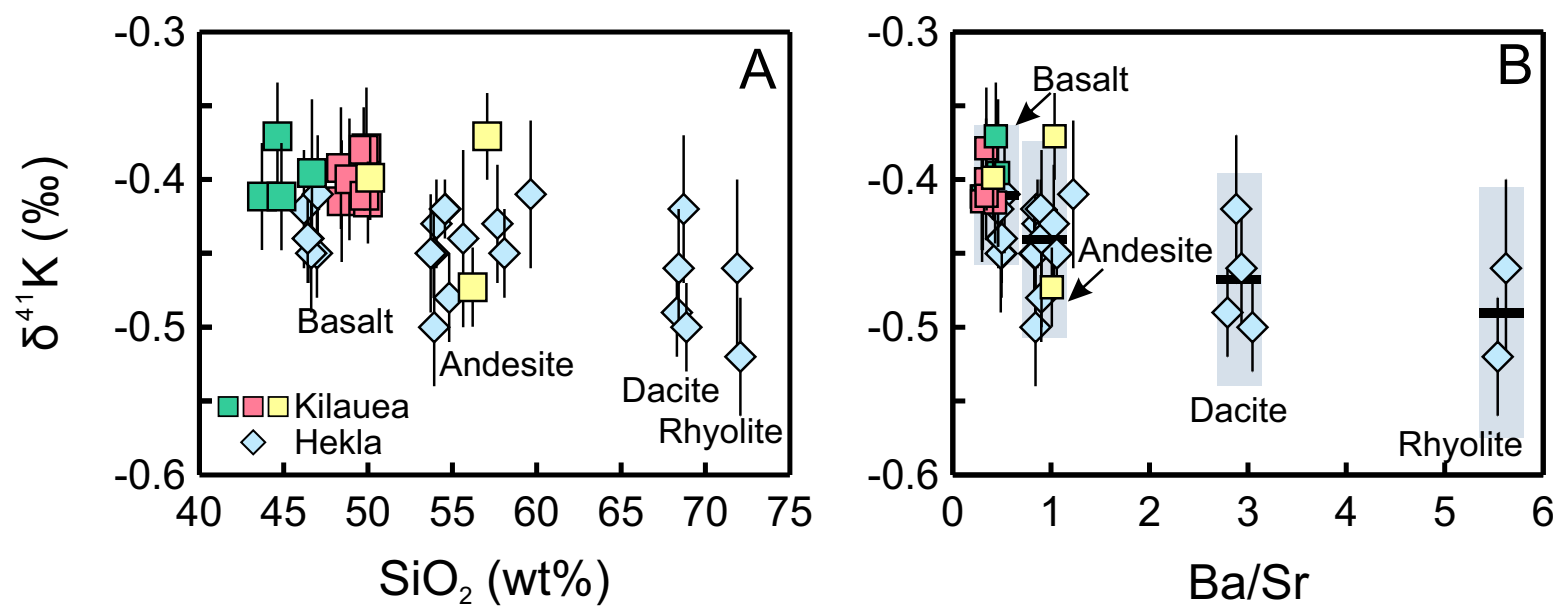

Figure 2 

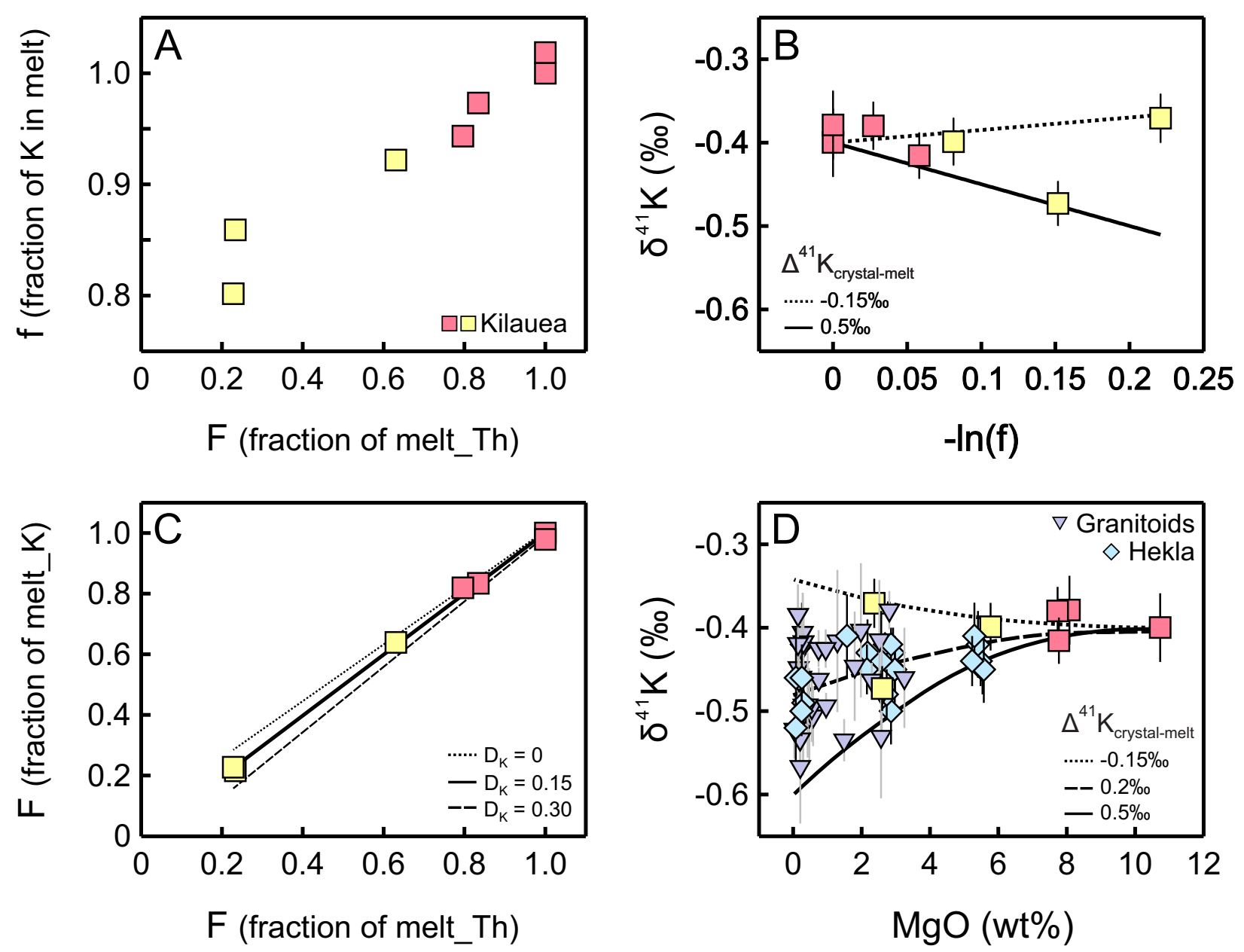

Figure 3 

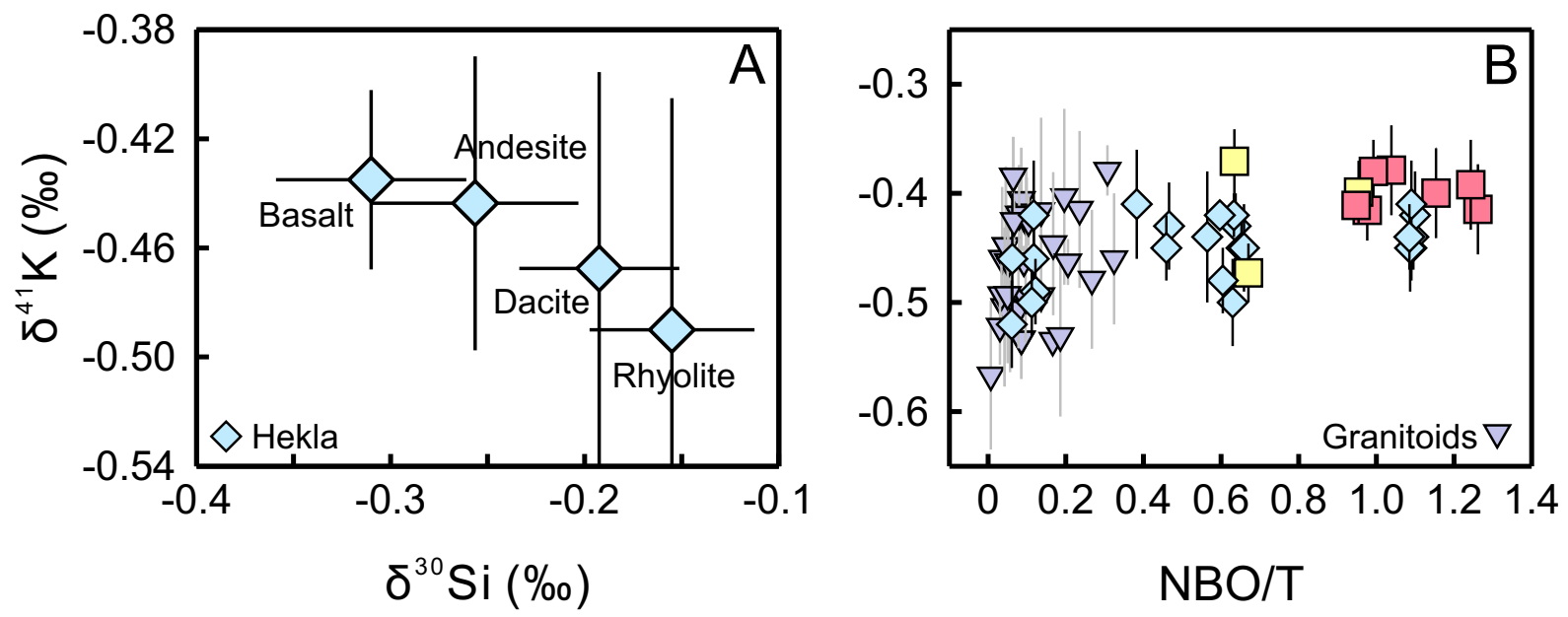

Figure 4 

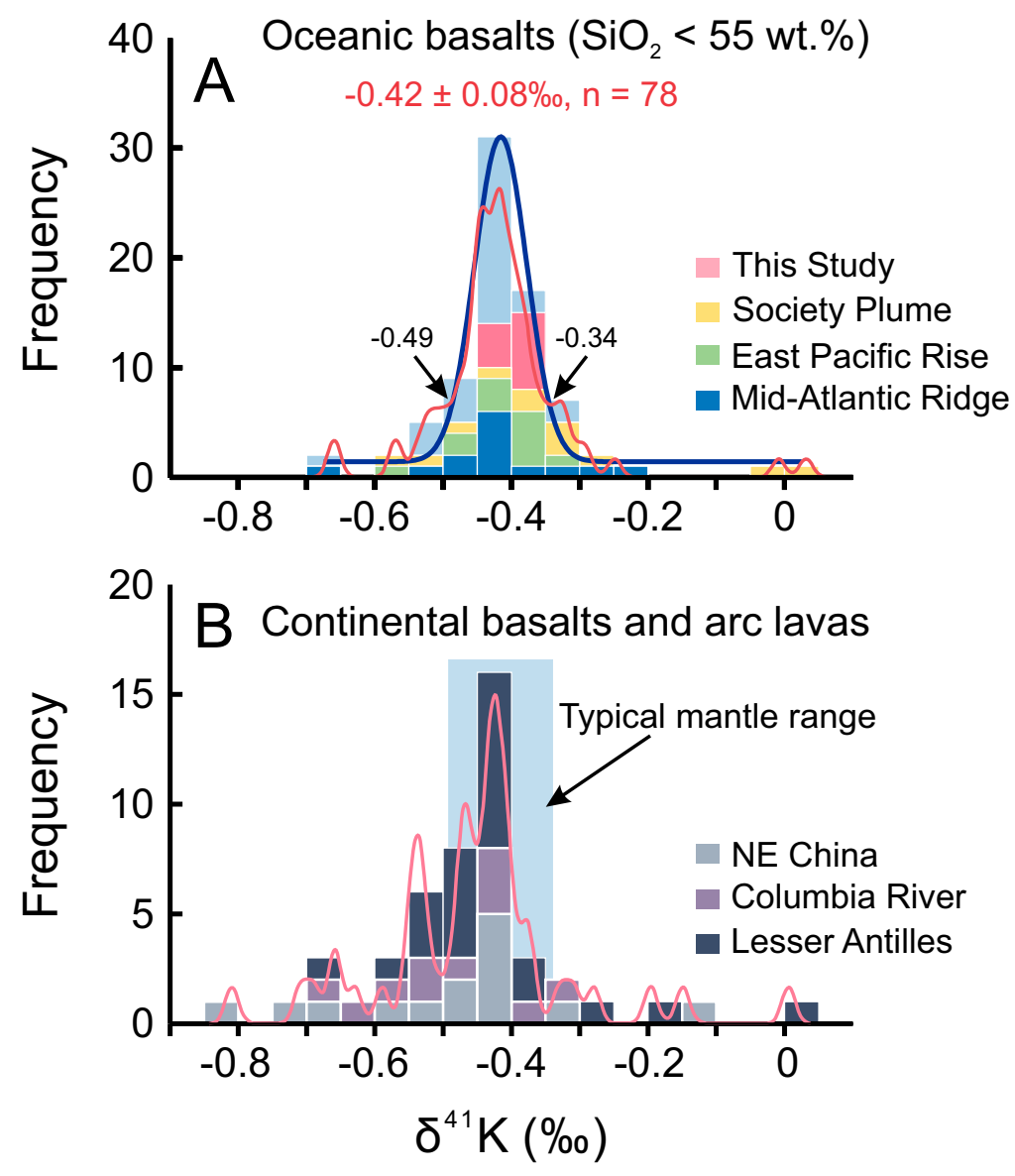

Figure 5 


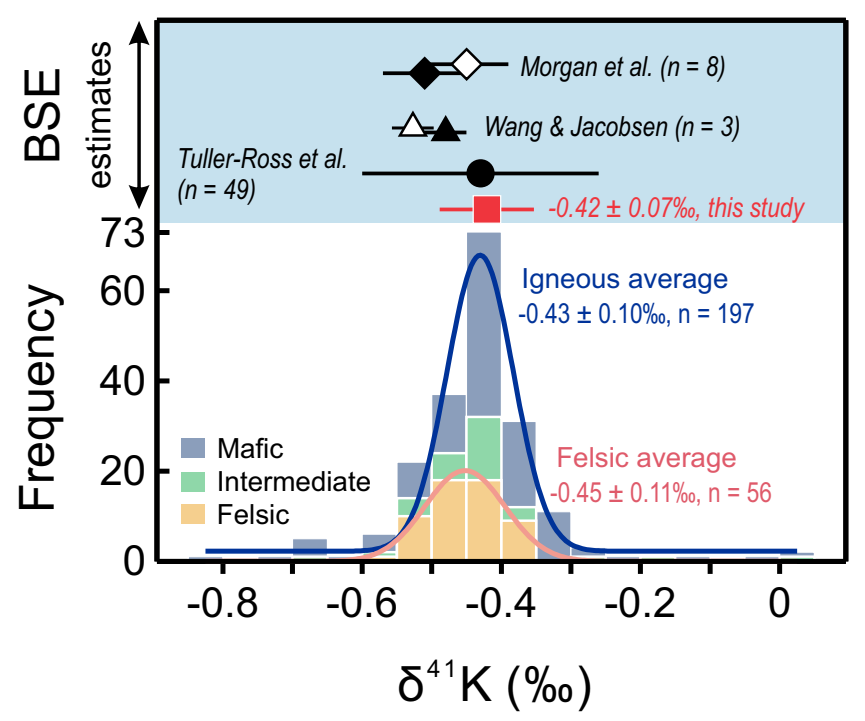

Figure 6 